\title{
We Have It too: A Strategy Which Helps to Grasp the JAPANESE WRITING SYSTEM FOR STUDENTS FROM OUTSIDE OF the Chinese Character Cultural Zone
}

\author{
Andrej BEKE ̌̆ \\ University of Ljubljana, Faculty of Arts \\ andrej.bekes@ff.uni-lj.si
}

\begin{abstract}
For beginner learners with non-Chinese character background complexities of Japanese writing system often represent an insurmountable obstacle. Yet closer look at different types of writing systems reveals that differences between them are more of a degree than of a kind. Present paper, based on this perception, argues for the employment of strategies based on a transfer of analogies between alphabet based writing systems such as English, to Japanese writing system. This would help beginner learners overcome cognitive and affective blockade, when beginning to learn Japanese writing.
\end{abstract}

Keywords: writing system; Chinese characters (kanji); pleremic; cenemic; analogy transfer

\section{Izvleček}

Kompleksnost japonskega sistema pisave pogosto predstavlja nepremagljivo oviro za tiste učeče se na začetni stopnji, ki ne izhajajo iz kulturnega kroga kitajske pisave. Natančnejši pogled na različne sisteme pisave pokaže, da razlike med sistemi niso toliko v sami zasnovi, ampak bolj v deležu, ki ga vsak tip pisave v danem sistemu zavzema. Izhajajoč iz takega pogleda na pisavo, pričujoči članek predlaga, za to, da bi učeči se premagal kognitivno in čustveno blokado ob prehodu na novi sistem pisave, uporabo učnih strategij, ki temeljijo na prenosu analogij iz sistema pisave lastnega učečemu se na ciljni, to je, japonski sistem pisave.

Ključne besede: pisave; kitajske pismenke (kanji); pleremsko; cenemsko; prenos po analogiji

\section{Introduction}

At present the majority of learners who learn Japanese do not learn it because they are especially interested in Japan's language and culture but for a wide spectrum of reasons, including study, work, or being married to a Japanese. Many live in Japan and for them, in order to be fully functional and autonomous members of community, learning Japanese implies also writing. For many of these learners, complexities and unfamiliarity of the writing system that they have to face when trying to learn Japanese

Acta Linguistica Asiatica, 3(1), 2013.

ISSN: 2232-3317, http://revije.ff.uni-lj.si/ala/

DOI: 10.4312/ala.3.1.75-84 
can be overwhelming, causing them to give up the effort, with all the negative societal consequences that follow such decisions.

Based on what kind of linguistic units are represented by individual units of writing, writing systems can be classified into semantically informed ones, i.e., pleremic, and semantically "empty" ones, i.e., cenemic. Pleremic systems are based on logography (word-writing), morphograpy (morpheme-writing) or both, and cenemic systems on writing units that represent individual sounds or syllables (Haas, 1976; French, 1976).

In general writing systems are not homogeneous, - i.e. based on a single principle of representing units of language with units of writing. On the contrary, they seem to be incorporating various principles of representation, either primarily, at the level of the relation of units of writing to units of language, or secondarily, at the level of organization of the units of writing motivated by the relation of this organization to units of language. Thus for example, Latin script, used in many European languages is primarily cenemic, letters (ideally) representing individual sounds, but employs spaces to signal division between words, and as such also secondarily incorporates logographic principle (Haas, 1976).

Japanese writing system is even more complex, employing Chinese characters (henceforth kanji) for logography units and two kana syllabaries for representing syllables (or more correctly mora). On the top of it, kanji are in principle used to represent morphemes when writing Chinese loan words and words when writing Japanese native words (Coulmas, 1989).

Requirements for a student to make a conceptual jump from one's own, primarily cenemic writing system, to a heavily hybrid pleremic-cenemic writing system such as Japanese, can be enormous. Reflecting on my experience teaching Japanese at the International Student Center at the University of Tsukuba and at the Japanese Studies program at the University of Ljubljana, I argue in this paper for a familiarizing strategy, sensitizing learners to the hybrid nature of their own writing systems, as a starting point to approach writing in Japanese, for the purpose of making learners' conceptual transition into the Japanese writing system easier.

\section{Previous research of kanji in Japanese language learning context}

There is an extensive theoretical research on kanji. Kaiser (2001, 1995), written in Japanese, are accessible considerations of the role of kanji from the point of view of writing science - including comparative perspective. Coulmas (1989) is an introduction to writing systems, while Coulmas (2003) is offers a rigorous linguistic analysis of various writing systems. Both works also treat characteristics of Japanese writing system. Tōdō (1969) is an interesting discussion of kanji in Japanese language context by an expert Chinese philologist, offering interesting insights into internal structure of kanji, potential of script reforms, script development and their present-day use. Haas (1976) and French (1976) discuss theoretical frameworks for classification of writing.

Research concerning learning kanji is also quite extensive. Haththotuwa Gamage (2003a) addresses learning strategies and the influence of learners "orthographic" 
background (kanji cultural area or not) on success of learning kanji, stressing the fundamental differences in strategies for the two types of learners. The same author (Gamage, 2003b) addresses language learning strategies in general. Also relevant to this paper is pointing out the "orthographic transfer" strategies, (Douglas, 1992). Nonetheless, such transfers are discussed only in the context of learners with Chinese character cultural zone background, often with harmful consequences. Possibilities of transfer strategies for learners with cenemic writing background, as a means to overcome conceptual hurdles in learning kanji, are not discussed. Douglas Ogawa (2004), in the context of learning and teaching kanji to learners with alphabetic background, discusses affective factors, while focusing more on issues such as the number of kanji, their relation to vocabulary, and absence of one to one encoding (such as on'yomi and kun'yomi "readings" etc.). Mental blockade, faced by learners when switching from an overall cenemic system to predominantly pleremic system, are not treated. Asaoka (2010) centers on issues such as retention and methods such as calligraphy, used to overcome the hurdles faced by Japanese learners. Rose (2010) investigates kanji learning strategies and offers important insights into until now rather neglected issue of self-regulation and other aspects of learning, while the important issue of trying to integrate kanji learning with the narrow and wide context of communication is not treated. Here, too, the issue of mental blockade in beginner learners is not dealt with.

\section{A sketch of options available in writing}

Writing in the narrow sense is the writing where units of writing are conventionally related to units of language (Coulmas, 1989). There is a major division regarding the level of linguistic units, stemming from the principle of double articulation (Martinet, 1960). According to this principle, continuous speech can be analyzed into discrete units of meaning, words and morphemes, this being the first articulation. Units of meaning can be further analyzed into semantically empty units of sound, this constituting the second articulation. Following French (ibid.) and Haas (ibid.), two basic options are pleremic and cenemic writing.

Pleremic writing is associated with the first articulation, i.e., with semantically informed, i.e., "full", units of meaning. Typical modern writing systems, extensively employing pleremic writing, are Chinese writing system and partly Japanese writing system, both based on the use of Chinese characters - kanji.

Cenemic writing is associated with the second articulation, i.e., with semantically empty units of sound such as syllables and individual sounds or phonemes. Typical representatives of cenemic writing are writing systems based on syllabic abugidas such as Ge'ez, Devanagari, etc., on alphabets such as Arab, Greek, Latin, Cyrillic, etc. (Daniels, 1990), and those employing syllabaries (e.g., partly Japanese, employing also katakana and hiragana syllabaries)

Ideography, on the other hand, is not writing in the narrow sense, since graphic signs in it are not primarily related to linguistic units. It is used to represent ideas and concepts directly and independently of language, in contexts such as traffic signs, mathematical formulas etc. (Haas, 1976). 
Writing systems also display secondary organization. Primarily pleremic writings, for example kanji, include a lot of phonetically motivated elements. Because the primary principle is pleremic, this happens at the level if internal structure of character ("inner form", cf. Coulmas ibid). On the other hand, cenemic writing systems include secondary organization motivated pleremically, i.e., secondary organization units being related to words/morphemes. In such cases, secondary organization is usually ruled by orthography of each particular language (Haas, 1976).

\section{A sketch of Japanese writing system makeup}

Japanese writing system is hybrid, pleremic-cenemic, employing various primary and secondary devices to represent language units.

\section{1 Primary devices}

Primary devices are the most conspicuous part of writing system, i.e., units of writing, graphic signs, directly associated with language units of meaning or sound.

\section{1. 1 Chinese characters - kanji}

In Japanese kanji are now conventionally used primarily to write verb stems, adjective stems, and nouns, in other words, "full meaning words", in line with what pleremic writing is expected to do. They are used in two ways. One is to write Chinese loan words or Chinese loan morphemes (on'yomi), for example 大学 daigaku (university) etc. The other is to write native Japanese words or morphemes (kun'yomi), for example 山 yama (mountain), etc. Neither of the two ways is straightforward, because the relationship between a character and the language element written with the character is not one-to-one. One character can be used to write several different words or morphemes. For example, character 頭 can encode several Chinese loan elements (morphemes) belonging to different periods of loaning ( $z u$, tō, etc., meaning "head"), and several different native Japanese words (atama, kashira, etc., also basically meaning "head", but belonging to different meaning domains (Coulmas ibid.).

There are also other uses, two of which will be mentioned here. One of them is the logographic use of compound Chinese words (jukujikun), to write native Japanese words, for example, 明日 for ashita, asu (tomorrow), 昨日 for kinō (yesterday), 大人 for otona (adult), etc. Nonetheless such examples are nowadays few and do not represent a significant additional load for beginner learners, therefore this paper will not deal with the issue. The other is the rebus-like use of kanji in many proper names (i.e., place names, family names etc.), such as 筑波 $t s u k u \bullet b a$ (a mountain in Kanto region), 伊那 $i \bullet n a$ (a town in the south of Nagano prefecture), etc. Often this use seems to be based on an older, Man'yogana style rebus use of kanji. 


\subsubsection{Hiragana and katakana}

Hiragana and katakana are used as supporting script in kanji-kana majiri style, and were developed as a necessity to write Japanese, a language highly inflected as compared with isolating Chinese, more accurately. Hiragana is at present used typically to write inflectional part of verbs and adjectives, adverbs, function words and often also full meaning words and proper names (as for instance in the name of Tsukuba city (つくば). Katakana is used typically for writing loan words and morphemes from languages other than Chinese, onomatopoeic words and for stressing (Tōdō, 1969; Coulmas, 1989).

\subsection{Secondary organization principles}

Secondary organization principles operate on primary graphic signs used to write a particular language. In Japanese, secondary organization is almost nonexistent.

Okurigana (inflection endings written in kana) do somehow contribute to the secondary organization by showing the inflectional ending of a verb or an adjective stem.

Wakachigaki (putting spaces between words) is problematic in Japanese because of the agglutinative nature of Japanese language, which makes it often very difficult to sharply distinguish between word boundaries. This is probably one of the reasons why dividing words with spaces did not catch up in Japanese orthography. Wakachigaki is used at the early elementary school level but is then discontinued. Another reason for not putting spaces between words is that at a more advanced level of writing ability, kanji employed to represent "full meaning" words can to some extent signal the boundary between individual words or morphemes, due to their different graphical impression.

While punctuation also belongs to the level of secondary organization, the principal marks such as ten (comma) and maru (period) delimit larger units such as phrases and clauses, which go beyond logography.

\section{Hybrid nature of primarily cenemic writing systems}

Inherently hybrid nature of cenemic systems can represent a welcome starting point for building consciousness about similarities, conductive to learners' intuitive grasp of principles on which the Japanese writing system is based.

\section{1 Alphabets - exemplified by the Latin alphabet in English}

Latin alphabet, used for writing English and a good number of other languages, from Albanian to Turkish, developed many conventions which in practice make the system hybrid, with inherent elements of pleremic writing principles. 


\section{1. 1 Pleremic use at the primary level of organization}

Such use is actually not so rare. Arab and Roman numbers used as subsidiary symbols within the alphabet, are used to write the words for numbers, and are thus pleremic. Further, all sorts of abbreviations, such as Dr (doctor), Mr. (mister), Mrs. (mistress), prof. (professor), Rev. (reverend), etc, are word signs derived from primarily alphabetic letters. Such abbreviations are conventionally representing full words, i.e., Dr is pronounced as "doctor" and not as /dí:x́:r/. Same is true also of acronyms of place names, widely used especially in the US, such s NY (New York), CA (California), etc., though there are exceptions, such as LA (Los Angeles, pronounced as /èléi/, thus behaving as a true acronym). In these cases an acronym may function either as derived logogram, referring to the original word (in cases such as NY and CA), or as a cenemically recoded version of the original place name (in cases such as LA). The same is basically true also of acronyms of organizations, such as NATO (North Atlantic Treaty Organization, pronounced /néitou/) etc. Such acronyms are very handy, because besides making the name shorter, they often conveniently hide the true purpose of the organization (mutual defense centered on North Atlantic, but being active in wars in Iraq and Afghanistan).

In addition, in more playful uses, examples such as "I $\vee$ NY" and its imitations, are not rare. This example is interesting, because it employs two logographic graphic signs, pictographic $\$ and alphabet derived NY. Similarly, smileys, Japanese "emoji" and similar, pictography based characters, such as $\boldsymbol{\nabla}$, (-), etc., are used in particular in electronic messaging to convey feelings and moods of the sender. Proliferation of pictographic signs also shows the need for direct, word-based option of writing, latent also in cenemic systems.

It can be seen that primarily cenemic systems, such as Latin alphabet based English writing system, are quite happy with a certain number of primary pleremic graphic signs (including the derived ones), since this in the right circumstances expedites communication.

\section{1. 2 Pleremic principles at the secondary level of organization}

Pleremic principles at the secondary level of organization, with words as linguistic units being conventionally and consistently signaled by the spaces between them, are also very instructive for drawing learners' attention to analogies with pleremic-cenemic systems such as Japanese.

Delimiting words with spaces was introduced in Latin alphabet in 7c.-8c. (Bruthiaux, 1993). Visual saliency of clearly individualized words contributed to the increase of accuracy and speed of reading. Individualized words thus function as a second degree logograms, in a way similar to phono-semantic compounds (形声字 / 形聲字 xingshēngzì, keiseiji) in kanji. Both are phonetically motivated, while at the same time they also relate to the coded linguistic unit at the word/morpheme level.

\subsubsection{Mixed pleremic-cenemic use}

Interestingly, mixed pleremic-cenemic use, analogue to okurigana inflectional endings in kanji-kana majiri writing in Japanese, is also found in many alphabet based 
writing systems, as for example in the case of ordinal numbers in English, French, etc. In English, for example, we have $1^{\text {st }}$ (FIRst), $2^{\text {nd }}$ (SECOnd), $3^{\text {rd }}$ (THIrd), $4^{\text {th }}$ (FOURth), etc. The principle is the same as in okurigana, the ending part of the word written with a logograph is spelled phonetically, to disambiguate and thus ease the reading. In the case of English, it is necessary to disambiguate between cardinal and ordinal numbers, and in the case of Japanese, between different shapes of the inflected words.

\subsection{Pleremic reflexes in abugidas and other phonetic scripts}

Other cenemic writing systems also employ secondary organization to delimit individual words. Modern Hebrew and Arabic in some cases employ different shapes of letters written at the beginning as opposed to the rest of a word. To separate words, Arabic alphabet used for writing Persian, Uyghur, Urdu and Pashto employs bigger size of the letter at the beginning of each word (the so called nasta $i \bar{i} q$ ). Korean hangul alphabet uses spaces. Many abugidas (being a hybrid between alphabetic and syllabic writing, also called alphasyllabic writing), employ word separating signs. For example in Ge'ez, words are separated by a kind of semicolon (Haile, 1996) while in devanagari abugida script used to write modern Hindi, words are separated by space. Related Khmer and Thai abugidas in modern use do not separate words.

\subsection{Syllabic reflexes in alphabetic writing}

This case seems to be limited to hangul, the Korean alphabet. In the case of hangul, letters are per definitionem grouped in syllabic groups, as for example in word

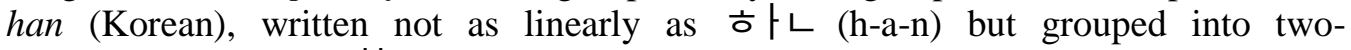
dimensional module: 한. This makes syllables visually salient, a great asset also in writing phonetically Chinese characters (hanja in Korean). Hanja are usually transliterated as syllables conforming to the Korean syllabic principles, and thus expressed as hangul letters grouped in syllables.

\subsection{Summary of analogies}

Even a rather superficial comparison of a complex mixed pleremic-cenemic system such as Japanese and primarily cenemic systems as exemplified by Latin alphabet in English, and also by many other alphabet or abugida based systems mentioned in sections 4 and 5, shows that these systems actually do share many analogue traits. In fact, there is no pure division between a pleremic or a cenemic system; actually all writing systems seem to be at least to some extent based on a mixture of the two principles. These analogue traits are summarized in the Table 1 below. As can be seen from the Table 1, these analogies seem to be strong enough to be able to say that the basic differences in writing systems are those of degree rather than those of a kind. 
Table 1: Analogies between Japanese and some cenemic writing systems

\begin{tabular}{|c|c|c|c|c|c|c|c|}
\hline & Writing system & Japanese & $\begin{array}{c}\text { Latin } \\
\text { (English) }\end{array}$ & Hangul & $\begin{array}{c}\text { Ge'ez } \\
\text { (Amharic) }\end{array}$ & Arab & Hebrew \\
\hline \multirow{4}{*}{ 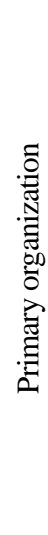 } & $\begin{array}{l}\text { Primary type } \\
\text { (main) }\end{array}$ & pleremic (kanji) & $\begin{array}{l}\text { cenemic } \\
\text { (alphabet) }\end{array}$ & $\begin{array}{l}\text { cenemic } \\
\text { (alphabet) }\end{array}$ & $\begin{array}{l}\text { cenemic } \\
\text { (abugida) }\end{array}$ & $\begin{array}{c}\text { cenemic } \\
\text { (alphabet) }\end{array}$ & $\begin{array}{l}\text { cenemic } \\
\text { (alphabet) }\end{array}$ \\
\hline & $\begin{array}{l}\text { Primary type } \\
\text { (subsidiary) }\end{array}$ & $\begin{array}{c}\text { cenemic } \\
\text { (kana syllabary) }\end{array}$ & $\begin{array}{c}\text { some } \\
\text { logographic } \\
\text { signs }\end{array}$ & $\begin{array}{c}\text { some } \\
\text { logographic } \\
\text { signs }\end{array}$ & $\begin{array}{c}\text { some } \\
\text { logographic } \\
\text { signs }\end{array}$ & $\begin{array}{c}\text { some } \\
\text { logographic } \\
\text { signs }\end{array}$ & $\begin{array}{c}\text { some } \\
\text { logographic } \\
\text { signs }\end{array}$ \\
\hline & $\begin{array}{l}\text { Pleremic and } \\
\text { cenemic mixing }\end{array}$ & $\begin{array}{c}\text { kanji-kana majiri } \\
\text { (mixed kanji- } \\
\text { kana) }\end{array}$ & traces & traces & traces & traces & traces \\
\hline & $\begin{array}{l}\text { okurigana } \\
\text { endings }\end{array}$ & $\begin{array}{c}\text { extensive use of } \\
\text { okurigana endings }\end{array}$ & $\begin{array}{c}\text { limited use } \\
\text { of endings } \\
\text { for ordinal } \\
\text { numerals }\end{array}$ & NA & NA & NA & NA \\
\hline \multirow{2}{*}{ 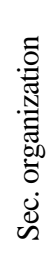 } & $\begin{array}{l}\text { word } \\
\text { separation }\end{array}$ & $\begin{array}{c}\text { word boundaries } \\
\text { vaguely shown by } \\
\text { different script } \\
\text { (kanji/kana or } \\
\text { hiragana/katakana) }\end{array}$ & spaces & spaces & $\begin{array}{l}\text { spaces, } \\
\text { double } \\
\text { dots etc. }\end{array}$ & $\begin{array}{c}\text { letter } \\
\text { shape, } \\
\text { letter size }\end{array}$ & $\begin{array}{l}\text { letter } \\
\text { shape }\end{array}$ \\
\hline & $\begin{array}{l}\text { syllable } \\
\text { grouping }\end{array}$ & present (kana) & NA & present & present & NA & NA \\
\hline
\end{tabular}

It is the transfer of these analogies inherent in cenemic scripts that has potential to help beginner learners of Japanese to surmount their conceptual blockade learning Japanese writing.

\section{Conclusions}

At the beginners level, when learners are faced for the first time with an unfamiliar and complex writing system, experience shows that the mental block towards such complexities often prevents learners from proceeding beyond the basic stage of learning, with all the societal and intercultural damage that goes with such developments.

The starting point of usual discussions of kanji learning strategies seems to always be beyond the initial contact with Japanese writing system. Such discussions are thus of no help at this critical point of learners' experience. Analogies summarized above are salient and intuitive enough to be easily transferred into Japanese writing system, thus providing a confused beginner with an intimate understanding of basic principles on which the Japanese writing system rests. Numerals and other subsidiary logographic signs in cenemic systems provide an intuitively accessible anchor for understanding the basic difference between pleremic and cenemic writing. Word separation and its connection with logography can amplify this understanding, in particular at the level when first phono-semantic compounds are introduced. Endings of ordinal numbers in 
English, French, Spanish etc., can serve to elucidate the way okurigana functions, at the stage when first verbs and adjectives are written with kanji.

With a wider range of cenemic systems examined in a greater detail perhaps even more analogies could be discovered. Also, expanding analogies between certain types of kanji inner form and traffic signs, mental crutches for understanding the role of bushu (semantic classifiers) could be provided, a topic worth further investigation. Nonetheless, what is essential in our case is that such analogies are not explanations per se but mental crutches which help the learner to grasp the Japanese (and by analogy also Chinese) writing system, and start understanding its functioning from within that system.

\section{References}

Asaoka, N. (2010). Introducing kanji strategies through japanese calligraphy [書道と組み合 わせての漢字ストラタジーの導入の試み]. 17th Princeton Japanese Pedagogy Forum, May 8 - May 9, 2010.

Bekeš, A. (1998). Vpliv Amerike na sodobni japonski jezik in pisavo. Azijske in afriške študije 2(1), 146-154.

Bekeš, A. (1999). Pojmovni okvir za klasificiranje sistemov kitajske in japonske pisave. Azijske in afriške študije 3(1/2), 218-238.

Bruthiaux, P. (1993). Knowing when to stop: Investigating the nature of punctuation. Language \& Communication 13(1), 27-43.

Coulmas F. (2003). Writing systems: An introduction to their linguistic analysis. Cambridge: Cambridge University Press.

Coulmas, F. (1989). The writing systems of the world. Oxford: Basil Blacwell.

Daniels, P. T. \& Bright, W. (Eds.). (1996). The world's writing systems. New York: Oxford University Press.

Daniels, P. T. (1990). Fundamentals of grammatology. Journal of the American Oriental Society 119(4), 727-731.

Douglas, M. O. (1992). Development of orthography-related reading/writing strategies by learners of Japanese as a foreign language. Unpublished $\mathrm{PhD}$ dissertation, University of Southern California.

Douglas, M. O. (January 14th, 2004). Learning and teaching kanji: For students from an alphabetic background. SenseiOnline - 40th Benkyoukailecture. Retrieved June 2013, from http://www.sabotenweb.com/bookmarks/about/douglas.html

French, M. A. (1976). Observation on the Chinese script and the classification of the writing systems. In W. Haas (Ed.), Writing without letters. Manchester: Manchester University Press.

Gamage, H. G. (2003a). Perceptions of kanji learning strategies: Do they differ among chinese character and alphabetic background learners? Australian Review of Applied Linguistics 26(2), 17-31.

Gamage, H. G. (2003b). Issues in strategy classifications in language learning: A framework for kanji learning strategy research. ASAA e-journal of asian linguistics \& language teaching. The Asian Studies Association of Australia. Retrieved June 2013, from http://www.arts.unsw.edu.au/languages/asaa_ejournal 
Gelb, I. J. (1963). A study of' writing. Chicago, London: The University of Chicago Press (revised edition, first published 1992).

Haas, W. (1976). Writing: the basic options. In W. Haas (Ed.), Writing without letters. Manchester: Manchester University Press.

Haile, G. (1996). Ethiopic writing. In P. T. Daniels, \& W. Bright (Eds.). (1996). The world's writing systems. New York: Oxford University Press.

Kaiser, S. [カイザーシュテファン] (1995). Sekai no nihongo kyōiku. [世界の日本語教育] $5,155-167$.

Kaiser, S. [カイザー シュテファン] (2001). Nihongo to kanji, Nihonjin to kanji -- Nihongo no hyōki to kokunaigai ni okeru toraekata ni tsuite [日本語と漢字 - 日本人と漢字一一日本 語の表記と国内外における捉え方についてーー] Kokugo-ka kyōiku [国語科教育] 50, 66-76.

Martinet, A. (1960). Elements of general linguistics. Chicago: Chicago UP.

Olson, D. R. (1993). How writing represents speech. Language \& Communication 13(1), 1-17.

Rose, H. (2003). Teaching learning strategies for learner success. Babel 38(2), 32-38.

Tôdô, A. (1969). Kango to nihongo (Chinese language and Japanese language). Tokyo: Shûei shuppan. 